Article

\title{
Analysis of the Methodology to Obtain Several Key Indicators Performance (KIP), by Energy Retrofitting of the Actual Building to the District Heating Fuelled by Biomass, Focusing on nZEB Goal: Case of Study
}

\author{
Rosaura Castrillón Mendoza ${ }^{1,2}$, Javier M. Rey Hernández ${ }^{2,3, *}$, Eloy Velasco Gómez ${ }^{2}$, \\ Julio F. San José Alonso ${ }^{2}$ and Francisco J. Rey Martínez ${ }^{2}$ \\ 1 Department of Energy and Mechanics, University Autónoma de Occidente Cali (UAO), Cali 760030, \\ Colombia; rcastrillon@uao.edu.co \\ 2 Department of Energy and Fluid Mechanics, School of Engineering (EII), University of Valladolid (UVa), \\ 47002 Valladolid, Spain; eloy@eii.uva.es (E.V.G.); julsan@eii.uva.es (J.F.S.J.A.); rey@eii.uva.es (F.J.R.M.) \\ 3 Higher Polytechnic College, European University Miguel de Cervantes (UEMC), 47012 Valladolid, Spain \\ * Correspondence: javier.rey@uva.es; Tel.: +34-983-423-366
}

Received: 20 November 2018; Accepted: 21 December 2018; Published: 28 December 2018

\begin{abstract}
In order to achieve the objectives of the European 20/20/20 strategy, and to obtain a greater energy efficiency, integration of renewable energies and the reduction of carbon emissions, a District Heating (DH) system has been designed by the University of Valladolid (UVa), Spain, one of the most important DH fed by biomass fuel in Spain, supplying heating and domestic hot water (DHW) to 31 buildings in Valladolid, the majority of them, educational buildings on the University Campus. The aims of this paper were to study the change from an energy system fueled by natural gas to District Heating by biomass in a building on the campus of the University of Valladolid-the School of Engineering (EII)-studying its consumption from its connection to the District Heating system. An energy management methodology such as ISO 50001 is carried out, applied to efficiency systems in buildings, thus establishing new criteria of sustainability and economic value. In this paper, energy management will also be analyzed in accordance with the proposed tools of an Energy Management System (EMS) applied to the EII building, through the measurement of energy parameters, calculation of thermal consumption, thermal energy savings as a result of the change from system to District Heating by biomass, economic savings, reduction of environmental impact and indicators of thermal efficiency $\mathrm{I}_{100}$ and CUSUM indicator. Finally, the primary renewable and non-renewable energy efficiency indicators for the new District Heating system will be determined. The concept of the near Zero Energy Buildings is defined in the European Union (EU) in order to analyze an approach to an nZEB which results from replacing the natural gas heating system by a biomass District Heating system.
\end{abstract}

Keywords: district heating; biomass; energy management in renovated building; nZEB

\section{Introduction}

The spread of university campuses in recent years has led to a significant increase in energy consumption. The total amount of energy consumption includes lighting, DHW, heating or air conditioning systems in all campus buildings.

Due to the large amount of energy consumption in these buildings, a policy of promoting energy savings, energy management, supply of energy useful to the final energy consumption, perfectly planned at a local scale, can maintain a standard of energy consumed on campuses in a controlled 
environment. The University as an institution is one that can best stimulate energy saving among other institutions by setting an example of its actions, pertaining to the consumption that it requires (Figure 1).

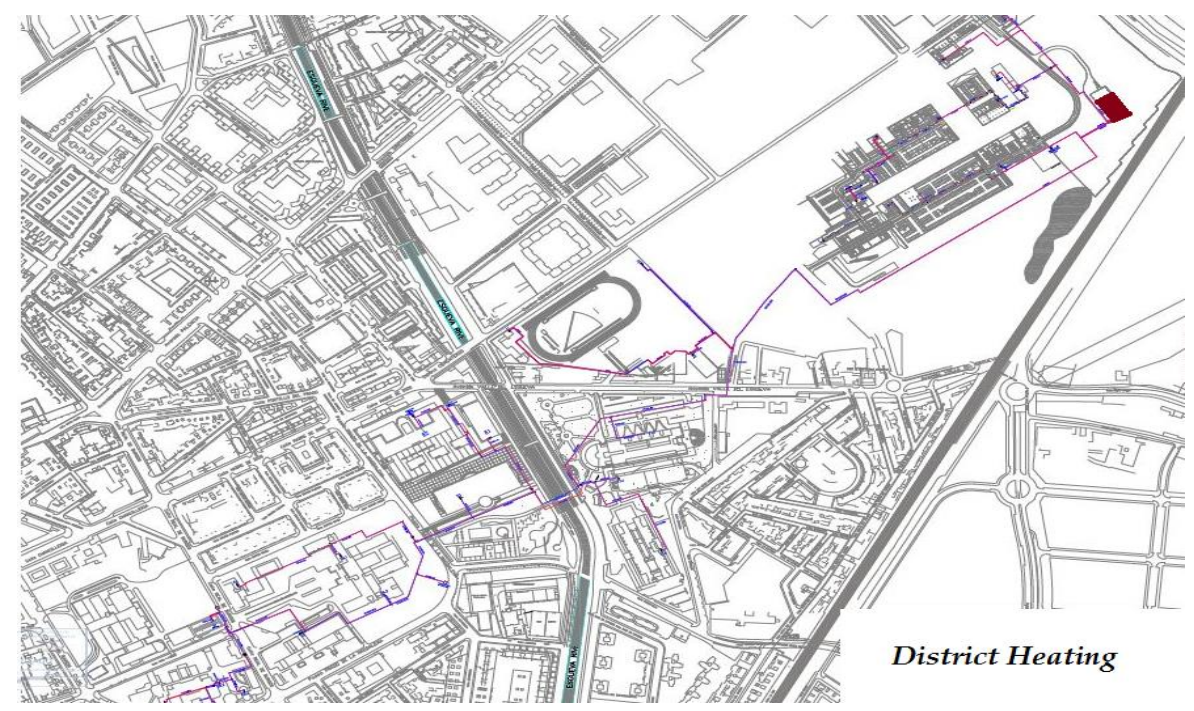

Figure 1. Plan view of connected buildings.

Among the different actions carried out by the University of Valladolid to reduce its carbon footprint, is the implementation of a DH system, making it to also the most important biomass DH in Spain, supplying heating and DHW to 31 buildings.

The thermal biomass generation plant has a power of $14 \mathrm{MW}$ with a total distribution network of $12 \mathrm{~km}$ in length, to supply an annual energy consumption of 22 million $\mathrm{kWh}$. The expected economic saving is $30 \%$ and the reduction in $\mathrm{CO}_{2}$ emissions of $6800 \frac{\text { tonCO}}{\text { year }}$. This represents a reduction in $\mathrm{CO}_{2}$ emissions of around 30\% of all our energy consumption (electricity and thermal) and an increase of $40 \%$ of energy production through renewables in our facilities.

The main purpose of this project is to achieve energy efficiency objectives and reduction of carbon emissions, through the implementation of the DH. The DH uses forest biomass as fuel, wood residues from near forests, a renewable energy source with low greenhouse gas emissions, which is cheaper than conventional fossil fuels, and allows us to achieve the objectives of the European strategy 20/20/20.

The use of renewable energy is an important commitment by the University of Valladolid to help control its carbon footprint through a significant reduction in $\mathrm{CO}_{2}$ emissions. It also means reducing energy dependence on fossil fuels. The current natural gas boilers will be maintained to ensure the supply of heating in the event of a disconnection of District Heating, thus ensuring thermal comfort in buildings.

The biofuel to be used are wood chips, with a grain size range from G50 to G100 and humidity between $20 \%$ and $40 \%$. Consumption is 7886 tons/year, of which the University will consume $6140 \frac{\text { tonCO }}{\text { year }}(77.87 \%), 183.74$ tons per year $(2.33 \%)$ by buildings of the City Council of Valladolid, and $1561.43 \frac{\text { tonCO }}{\text { year }}(19.80 \%)$ by buildings of the Government of Castilla y León.

The annual energy generation in 2016-2017 was 22,069 MWh per year to the whole of the network, of which 17,188 MWh correspond to the consumption of the UVa (77.87\%), 515,180 kWh correspond to buildings of the City Council of Valladolid (2.33\%) and 4,366,685 kWh belong to buildings of the Junta de Castilla y León (19.80\%).

Some current research focuses on the study and application of the Thermal District concept. Mazhar et al. [1] conducted a review of district heating systems, which highlights the importance of modernizing heating systems to reduce greenhouse gas emissions and contribute to sustainability, for which district heating $(\mathrm{DH})$ systems are considered the future trend. In the view of Gao et al. [2], District Heating offers greater advantages than traditional heating systems, including energy savings, 
regulation and control, which represents a great potential for development and a broad market outlook for the future. Regarding DH development, Lund et al. [3] presented a vision of the future of district heating systems and technologies and their role in a sustainable energy future. Wener [4] presented the background and current position of district heating and cooling in Sweden. The review structure considers market, technical, supply, environmental, institutional and future contexts. Lygnerud and Werner. [5] concluded in their study of 107 heat recovery systems in Swedish industry that the recovery of excess industrial heat using DH systems can be characterized by high political interest, high potential, low utilization and often high profitability. A paper submitted by Schmidt [6] exposes the cooperative work carried out together with the International Energy Agency (IEA) on thermal districts, determined that low-temperature district heating is a key technology that allows to increase the integration of renewable and residual energy for heating and cooling. Turski-Michal and Sekret-Robert [7] analyzed 63 heating stations in Poland in order to determine the energy effect of using buildings and the district heating network as thermal energy storage to compensate for the reduced heat output of the district heating system. In the investigation some parameters are often underestimated, such as the effect of the incidence of external temperature and the duration of outdoor temperature on the production of heat from DH systems. In Vienna, Fallahnejad et al. [8] studied the impacts of key DH parameters (ceilings, network costs, DH participation and extension), in which they determined that increasing DH market share in HD areas under a given network cost limit significantly reduces average network costs. Furthermore, that expanding the DH system without increasing market share in the DH areas does not effectively increase the DH share of the total heat demand and leads to higher average network costs. Restoration of existing buildings is considered a way to reduce energy use and carbon emissions in building stock. In [9] the impact of renovating a single-family home with different district heating systems under restoration packages chosen to represent typical but innovative ways to improve the energy efficiency and indoor climate of a single-family home was studied. In Bavaria, the performance of six small-scale district heating systems (DH) was monitored for 12 months in order to identify typical optimization potentials and develop standards for performance monitoring, analyze extensive operational data and evaluate Key Performance Indicators (KPIs). The KPI showed strong fluctuation and variation between different $\mathrm{DH}$ indicating that the main potential was found in the control of $\mathrm{DH}$ [10].

One of the challenges for near Zero Energy Consumption Buildings (nZEB) is thermal conditioning systems, Wu et al. [11] compared the energy performance of HVAC systems for a zero-grid energy residential building (nZEB) in different climate zones in the United States, where air conditioning represented $23.8 \%$ to $72.9 \%$ of the total energy of the building, depending on the air conditioning option and climate zone. In [12] whether nZEB standards applied to Italian school buildings guarantee good thermal conditions inside and which building configuration is the most favored was studied. Nielsen and Möller [13] examined the excess heat production of nZEBs in DH, determined that the excess heat of $\mathrm{nZEBs}$ can benefit DH systems by decreasing the production of fuel-using production units. In DH areas where the heat demand in the summer months is already covered by renewable energy, adding seasonal heat storage is essential to achieve nZEB status in terms of efficiency indicators as an alternative to track changes in efficiency and savings obtained according to the improvements implemented. Sekki et al. [14] showed that energy efficiency can be measured using alternative indicators and confirmed that different indicators have a different impact on the results showing efficiency. In the cases studied, energy savings can be achieved by investing in technical measures or operating the building automation system based on actual occupancy. On the other hand, Abu et al. [15] reviewed the Energy Efficiency Index (EEI) as an indicator to measure the performance of energy consumption in a building, with the forecast of energy consumption in a building being an important strategy to achieve the goal of reducing energy demand as well as improving energy efficiency. A review of how to quantify the Environmental Building Performance (EBP) is conducted by Maslesa et al. [16] through a systematic review of the literature where the information obtained is valuable to decision makers and facility managers in the process of implementing an environmental strategy and focusing on improving the EBP. It also concludes that 
buildings as products are complex structures with a long service life compared to most other products and induce considerable environmental impacts throughout their life cycle. As for the importance of integrating SGEn in the industrial and service sector, ISO 50001 [17] provides benefits for the industrial and service sectors. It is estimated that the standard, applied to different economic sectors, could influence savings of up to $60 \%$ in the world's energy consumption according to studies by Van der Hoeven [18]. In terms of methodologies to implement SGEn, Castrillón et al. [19] reported their results of the implementation of SGIE in a wet cement production facility, which showed an increase in energy efficiency associated with a reduction in electricity consumption of $4.6 \%$, achieved without investment. This means that only through the innovation of processes through applied management technologies, in addition to the adoption of a culture of efficient energy management and continuous improvement. Benedetti et al. [20] also presented a new methodology for managing energy performance through the development, analysis and maintenance of energy performance indicators in manufacturing plants, taking into account the requirements of ISO 50001:2011 and ISO 50006:2014. The proposed methodology allows for the immediate identification of energy performance deviations from the manufacturing plant through the monitoring of Energy Performance Indicators over time and the identification of possible causes and responsibilities for such deviations. Saadi et al. [21] described the results of a study that has been carried out to reduce the energy consumption of a library building in the warm Omani climate. The project follows a systematic approach of collecting data from the maintenance department and projects, performing an energy audit and generating a building simulation model. To learn the real scenario of building energy management facilities, Afroz et al. [22] conducted a study in an institutional building at Murdoch University (Australia), which has incorporated leading-edge technologies over the past two decades. Through this case study analysis, relevant information is revealed that will bring benefits to energy management staff as well as researchers in this area, showing that an efficient energy management system in commercial or institutional buildings can reduce energy consumption and operating costs and provide a comfortable and healthy indoor environment. In terms of management tools and techniques as well as statistics, Castrillón and González [23] set out the procedures for validating the energy indicators and baselines needed in the energy planning of any institution and its subsequent implementation of an energy planning management system. This represents a reduction of $75 \%$ of emissions associated with the thermal supply of heating, allowing us to reduce our carbon footprint. This will also allow us to improve the energy certification of campus buildings. A building that is connected to a network improves its energy rating, an improvement that can be even greater when the network of biomass heaters is used, as in this case.

\section{Case Study}

The Engineering School (EII), is an educational building, mainly dedicated to teaching and research. It has a base area of $20,397 \mathrm{~m}^{2}\left(16,691.4 \mathrm{~m}^{2}\right.$ useful), distributed over four floors and the orientation of the main façade is southwest. (Figure 2).

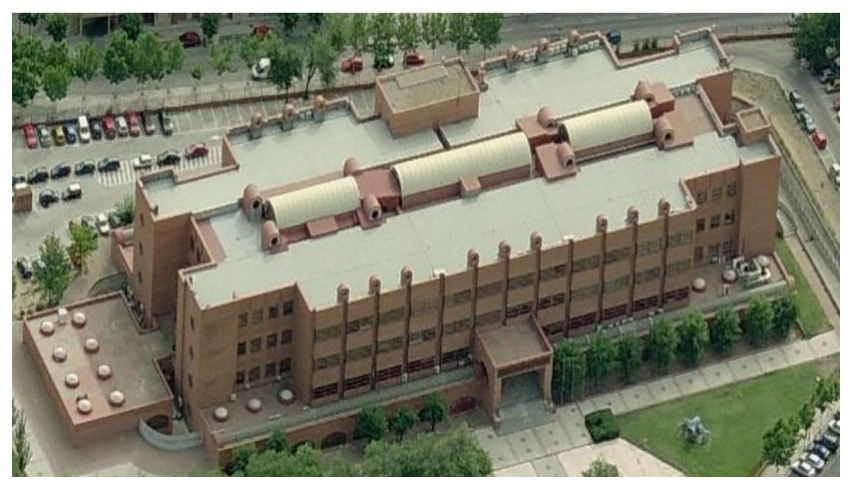

Figure 2. School of Industrial Engineering (EII) building. 
Table 1 lists the features and facilities of the EII building.

Table 1. Features of the building.

\begin{tabular}{|c|c|c|c|c|c|}
\hline System/Fuel & Lighting: & Heating: & HVAC & Other Equipment & $\begin{array}{c}\text { Working Time and } \\
\text { Set Point }\end{array}$ \\
\hline $\begin{array}{c}\text { Gas Boilers } \\
\text { (NG) }\end{array}$ & $\begin{array}{l}\text { LED and } \\
\text { fluorescence with } \\
\text { electromagnetic } \\
\text { ballast T5 }\end{array}$ & $\begin{array}{c}\text { Natural Gas boilers of } \\
540 \mathrm{~kW} \\
\text { "REMEHA" model } \\
\text { "Gas-3B/13-Duo" } \\
\eta=0.78\end{array}$ & $\begin{array}{l}\text { Individual } \\
\text { Split-type } \\
\text { equipment. 19 Air } \\
\text { Handling Units } \\
\text { (AHU) }\end{array}$ & $\begin{array}{c}\text { Elevators, } \\
\text { computers and } \\
\text { laptops, printers, } \\
\text { laboratory } \\
\text { equipment, etc. }\end{array}$ & $\begin{array}{l}\text { Weekdays ( } 8 \text { a.m. to } \\
10 \text { p.m.). } \\
\text { Saturdays }(9 \text { a.m. to } \\
2 \text { p.m.). } \\
\text { Set point }\left(21^{\circ} \mathrm{C}\right)\end{array}$ \\
\hline $\begin{array}{c}\mathrm{DH} \\
\text { (Biomass) }\end{array}$ & $\begin{array}{l}\text { LED and } \\
\text { fluorescence with } \\
\text { electromagnetic } \\
\text { ballast T5 }\end{array}$ & $\begin{array}{c}119,000 \mathrm{~L} \text { of backup tank } \\
\text { DH substation with flat } \\
\text { plate heat exchanger } \\
\text { Biomass Boilers } 19 \mathrm{MW} \\
\quad \eta=0.85\end{array}$ & $\begin{array}{l}\text { Individual } \\
\text { Split-type } \\
\text { equipment } \\
\text { 19 Air Handling } \\
\text { Units (AHU) }\end{array}$ & $\begin{array}{l}\text { Elevators, } \\
\text { computers and } \\
\text { laptops, printers, } \\
\text { laboratory } \\
\text { equipment, etc. }\end{array}$ & $\begin{array}{l}\text { Weekdays ( } 8 \text { a.m. to } \\
10 \text { p.m. }) \\
\text { Saturdays }(9 \text { a.m. to } \\
2 \text { p.m. }) \\
\text { Set point }\left(21^{\circ} \mathrm{C}\right)\end{array}$ \\
\hline
\end{tabular}

The heat exchange system between the DH and the EII is done through a secondary installation in the facilities of the building, formed by a flat plate exchanger, elements regulating and controlling the heating operation, and a discharge pump, which distributes the fluid to the different areas of the building (Figure 3).

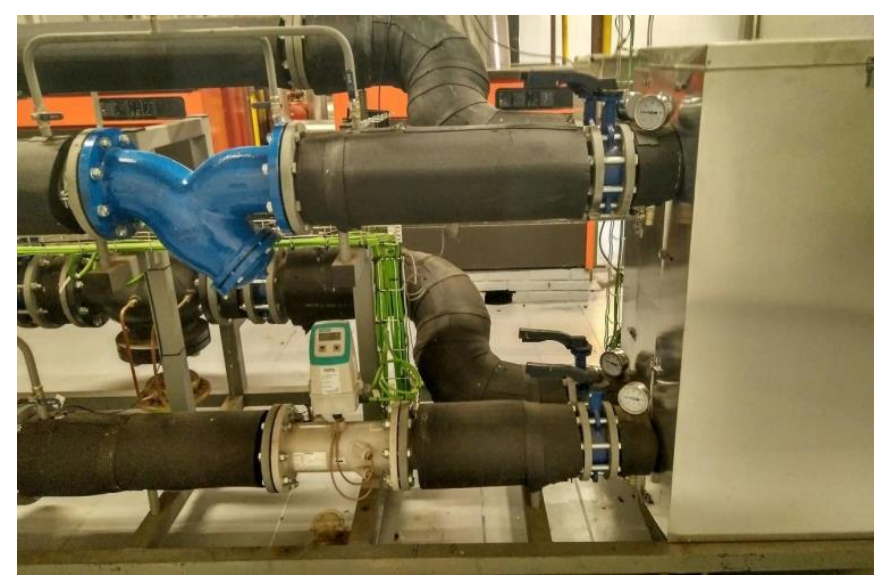

Figure 3. Heat exchanger substation in the facilities at the EII Building.

The system consists of two circuits, the primary circuit, from the Central Heat Power (CHP) to the building facilities where the heat exchanger is located, and the secondary circuit, from the heat exchanger to the heat supply to the building.

The connection between the $\mathrm{DH}$ and the substation of the building is from underground pipes that lead to the installations of the building. Once the supply and return pipes reach the facilities at EII building, the pressure and temperature from the $\mathrm{DH}$ is regulated with the heat exchanger to the necessary conditions for the heating demand of the building. Both the supply and return temperatures of the system ought to be regulated in such a way that the temperature that reaches the heat exchanger from the central heating plant is $90^{\circ} \mathrm{C}$ and the temperature at the outlet of the heat exchanger in the return pipe towards the central heating plant is close to $70{ }^{\circ} \mathrm{C}$, with a thermal gap of approximately $20^{\circ} \mathrm{C}$.

In order to visualize, control and manage at any time the operation of the installation, a dynamic monitoring is developed through sensors and automatons that register data, which are exported and saved in a Supervisory Control And Data Acquisition (SCADA). In this way, any possible failure or warning can be read quickly and the exact location of the problem can be visualized (Figure 4). 


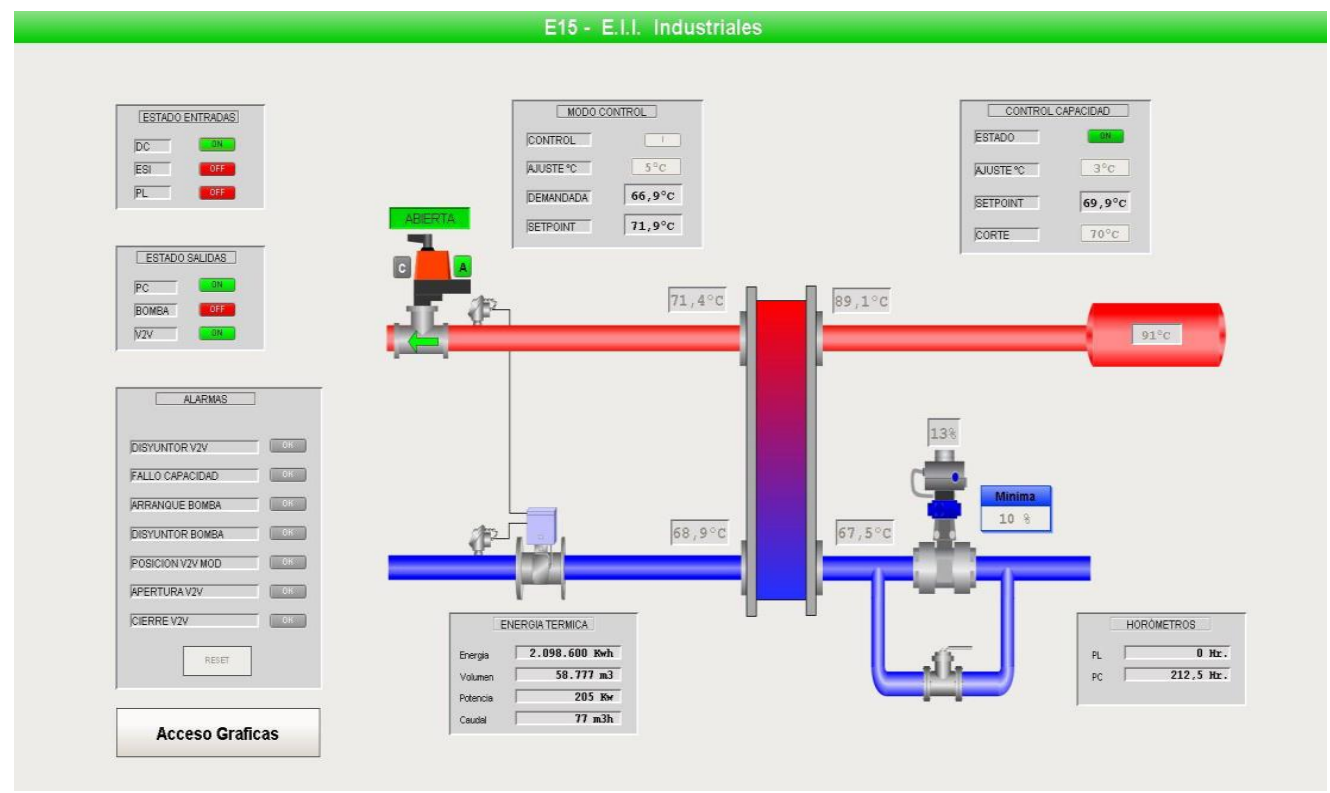

Figure 4. Screenshot of the EII Heat Exchanger substation SCADA.

The data provided by the implemented monitoring system is accessed via SCADA, which manages the $\mathrm{DH}$ generation and the heat exchange substations connected to DH. With the SCADA, all the energy parameters being measured by sensors can be visualized, represented and studied in depth. The consumption by the generation and energy demand are displayed in real time, in addition to being able to observe an instant control of the heat exchangers of each building.

The SCADA implemented in the system facilitates the analysis and studies of historical consumption and can generate reports on the development of each system together or separately, comparing values between the different buildings connected to the DH. In addition all this data can be exported to Excel files and simulation files, enabling their study through other software programs.

In addition, there are different sensors spread throughout the building that record the different energy and comfort parameters in real-time, delivered through a Modbus network to a dynamic monitoring tool, where are stored for subsequent study, using them as an energy management tool for the building.

The dynamic monitoring of energy parameters through SCADA, provides information on the use of energy consumed as an energy management tool. In this way, it has been possible to obtain the thermal and electrical energy consumption, where this consumption occurs and the conditions of the spaces where this energy is being supplied. Figure 5 shows the dynamic monitoring of the thermal parameters in the heating system, such as the power generated at the EII building during a period of nine standard winter days.

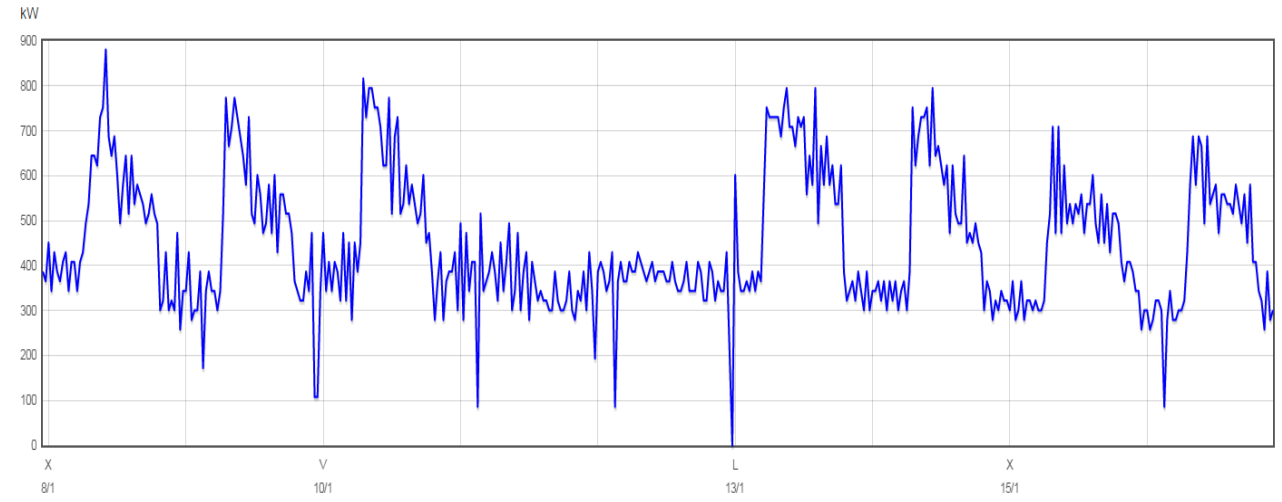

Figure 5. Screenshot of EII SCADA. Thermal power consumed in a winter period. 


\subsection{Thermal Consumption}

The thermal primary energy consumption per year in $\mathrm{kWh}$ and the thermal efficiency indicator $\left(\frac{\mathrm{kWh}}{\mathrm{m}^{2}}\right)$ of Natural Gas in the EII Building at the UVa, between 2006 and 2017, are shown in Table 2, where it can be observed that in 2010 there was a maximum due to the extreme temperatures that winter, and the necessity of higher heating consumption. There is also a reduction in the thermal consumption of Natural Gas from 2015 to 2017, when the DH fueled by biomass begins to work, thus the NG boilers just work as backup.

Table 2. Natural Gas Consumption from 2006 to 2017.

\begin{tabular}{ccc}
\hline \multirow{2}{*}{ Year } & \multicolumn{2}{c}{ Natural Gas } \\
\cline { 2 - 3 } & KWh & KWh/m $\mathbf{m}^{\mathbf{2}}$ \\
\hline 2006 & $1,264,550$ & 75.76 \\
2007 & $1,415,661$ & 84.81 \\
2008 & $1,632,630$ & 97.81 \\
2009 & $1,585,339$ & 94.98 \\
2010 & $2,569,220$ & 153.92 \\
2011 & $1,639,719$ & 98.24 \\
2012 & $1,805,694$ & 108.18 \\
2013 & $1,510,476$ & 90.49 \\
2014 & $1,229,459$ & 73.66 \\
2015 & $1,131,687$ & 67.8 \\
2016 & 87,716 & 5.26 \\
2017 & 14,912 & 0.88 \\
\hline
\end{tabular}

In Table 3, the natural gas thermal consumption of in $\mathrm{kWh}$ and the thermal efficiency indicator $\left(\frac{\mathrm{kWh}}{\mathrm{m}^{2}}\right)$ are shown monthly during the last years, from 2014 to 2017 .

Table 3. Natural Gas consumption and indicators from 2014 to 2017.

\begin{tabular}{ccccccccc}
\hline \multirow{2}{*}{ Month } & \multicolumn{2}{c}{$\mathbf{2 0 1 4}$} & \multicolumn{2}{c}{$\mathbf{2 0 1 5}$} & \multicolumn{2}{c}{$\mathbf{2 0 1 6}$} & \multicolumn{2}{c}{$\mathbf{2 0 1 7}$} \\
\cline { 2 - 9 } & $\mathbf{k W h}$ & $\mathbf{k W h} / \mathbf{m}^{\mathbf{2}}$ & $\mathbf{k W h}$ & $\mathbf{k W h} \mathbf{m}^{\mathbf{2}}$ & $\mathbf{k W h}$ & $\mathbf{k W h} / \mathbf{m}^{\mathbf{2}}$ & $\mathbf{k W h}$ & $\mathbf{k W h} \mathbf{m}^{\mathbf{2}}$ \\
\hline January & 258,821 & 15.51 & 377,448 & 22.61 & 33,617 & 2.01 & 2834 & 0.17 \\
February & 276,638 & 16.57 & 360,341 & 21.59 & 2294 & 0.14 & 0 & 0 \\
March & 208,852 & 12.51 & 243,979 & 14.62 & 12,292 & 0.74 & 851 & 0.05 \\
April & 116,325 & 6.97 & 95,293 & 5.71 & 12,395 & 0.74 & 5184 & 0.31 \\
May & 18,881 & 1.13 & 31,520 & 1.89 & 2912 & 0.17 & 4587 & 0.27 \\
June & 0 & 0 & 0 & 0 & 0 & 0 & 0 & 0 \\
July & 0 & 0.02 & 0 & 0 & 0 & 0 & 0 & 0 \\
August & 0 & 0 & 0 & 0 & 0 & 0 & 0 & 0 \\
September & 0 & 0 & 0 & 0 & 574 & 0.03 & 0 & 0 \\
October & 993 & 0.06 & 5905 & 0.35 & 11,345 & 0.68 & 672 & 0.04 \\
November & 173,818 & 10.41 & 13,498 & 0.81 & 8908 & 0.53 & 464 & 0.03 \\
December & 174,875 & 10.48 & 3703 & 0.22 & 3379 & 0.2 & 320 & 0.02 \\
\hline
\end{tabular}

In the variation of the monthly NG thermal efficiency indicator $\left(\frac{\mathrm{kWh}}{\mathrm{m}^{2}}\right)$, of the EII in the years 2014 to 2017, it can be noted that the months of June, July, August and in some years the month of September, due to the fact that the external temperature is high and no heating is needed, there is no thermal consumption. However, there is a cost due to the payment of the fee for contracting this NG service. From September 2015, the DH was incorporated, this year still experimentally, which reduced the thermal consumption of NG as well as the cost of heating.

As for the cost, the annual consumption of NG for heating shows that the NG tariff was stable, with service contracting rates distributed as follows: $135.13 \frac{\epsilon}{\mathrm{kWh}}$ in $2014,137.42 \frac{\epsilon}{\mathrm{kWh}}$ in $2015,136.54 \frac{\epsilon}{\mathrm{kWh}}$ 
in 2016 and $108.66 \frac{€}{\mathrm{kWh}}$ in 2017. Another important consideration is that in September 2015, both the energy and cost decreased thanks to the supply of the DH network.

The biomass District Heating $(\mathrm{DH})$ system began to provide heating service to the entire campus of the UVa and therefore the EII building in 2015/2016, with the year 2016/2017 being the second year of operation of the DH network. Table 4 shows the variation in thermal consumption of DH fed with biomass in kWh and the thermal efficiency indicator of biomass in the EII during the different months of the year.

Table 4. Primary energy consumption and energy efficiency indicator for DH fueled by biomass from 2015 to 2017.

\begin{tabular}{ccccccc}
\hline \multirow{2}{*}{ Month } & \multicolumn{2}{c}{$\mathbf{2 0 1 5}$} & \multicolumn{2}{c}{$\mathbf{2 0 1 6}$} & \multicolumn{2}{c}{$\mathbf{2 0 1 7}$} \\
\cline { 2 - 7 } & $\mathbf{K W h}$ & $\mathbf{K W h} / \mathbf{m}^{\mathbf{2}}$ & $\mathbf{K W h}$ & $\mathbf{K W h} / \mathbf{m}^{\mathbf{2}}$ & $\mathbf{K W h}$ & $\mathbf{K W h} / \mathbf{m}^{\mathbf{2}}$ \\
\hline January & 0 & 0 & 167,500 & 10.04 & 283,300 & 16.97 \\
February & 0 & 0 & 224,400 & 13.44 & 205,600 & 12.32 \\
March & 0 & 0 & 164,700 & 9.87 & 169,800 & 10.17 \\
April & 0 & 0 & 126,700 & 7.59 & 53,800 & 3.22 \\
May & 0 & 0 & 18,900 & 1.13 & 13,800 & 0.83 \\
June & 0 & 0 & 0 & 0 & 0 & 0 \\
July & 0 & 0 & 0 & 0 & 0 & 0 \\
August & 0 & 0 & 0 & 0 & 0 & 0 \\
September & 0 & 0 & 0 & 0 & 0 & 0 \\
October & 53,000 & 3.18 & 28,700 & 1.72 & 8100 & 0.49 \\
November & 173,200 & 10.38 & 186,100 & 11.15 & 137,100 & 8.21 \\
December & 126,100 & 7.55 & 177,400 & 10.63 & 219,700 & 13.16 \\
\hline
\end{tabular}

The evolution of thermal consumption of biomass, as well as the thermal efficiency indicator, shows the impact that the incorporation of viomass, through the DH system, has had for the EII as a substitute fuel for NG in recent years. Figure 6 shows the evolution of the thermal efficiency indicator for biomass as a function of the months in the annual period 2015-2017.

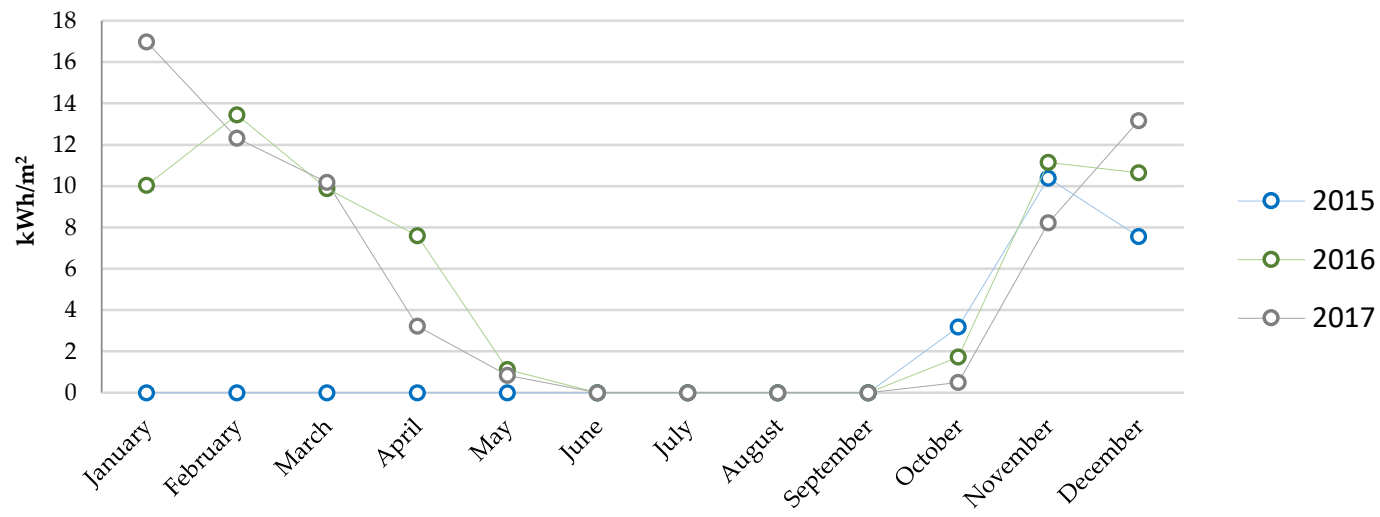

Figure 6. Evolution of the thermal efficiency indicator for biomass use 2015-2017.

With regards to the composition of the EII's energy matrix, in 2014 the NG heating system was installed, having only high thermal consumption in the months when the heating started. At that time the distribution of annual energy consumption corresponded to 56\% thermal consumption of NG and the remaining $44 \%$ is a consumption of electricity.

In 2015, the implementation of the DH began, which began to heat the EII in September, however due to climate issues, heating consumption in this month was not necessary. Once the DH began to operate, there was a decrease in NG consumption, resulting in an annual distribution of thermal consumption for that year of $14 \%$ biomass, and $44 \%$ NG. Due to the fact that the DH was operating in experimental mode with frequent stoppages for verification and balancing, the EII was still using 
the old NG system to allow for proper heating. The remaining $42 \%$ corresponds to the electricity consumption of the EII.

In 2016, the DH fueled by biomass started to operate year round, with the support of the NG boiler system of the EII. The distribution of the energy matrix throughout this year corresponded to a thermal consumption of $51 \%$ of biomass consumption, and $4 \%$ of NG, and the remainder is electricity consumption. In this year and subsequent ones the percentage of NG consumption is very low compared to the biomass consumption. In 2017, the second year of operation of the DH network, the installation was already at an optimum point of operation due to its balance. In this way the distribution of energy consumption percentage of the EII, corresponds to a thermal consumption of $72 \%$ of biomass consumption and $1 \%$ of NG. As a result, NG consumption is negligible compared to biomass consumption. The annual analysis is shown in Table 5 , where it is possible to decrease both the $\mathrm{kWh} / \mathrm{m}^{2}$ indicator and the economic expenditure $€ / \mathrm{m}^{2}$.

Table 5. Indicator of thermal efficiency $\left(\frac{\mathrm{kWh}}{\mathrm{m}^{2}}\right)$ and energy cost Indicator of biomass from 2015 to 2017.

\begin{tabular}{ccccc}
\hline Biomass & $\boldsymbol{\epsilon}$ & $\boldsymbol{\epsilon} / \mathbf{m}^{\mathbf{2}}$ & $\mathbf{K W h}$ & $\mathbf{K W h} / \mathbf{m}^{\mathbf{2}}$ \\
\hline 2015 & $28,359.93$ & 1.7 & 352,300 & 21.11 \\
2016 & $88,060.89$ & 5.28 & $1,094,400$ & 65.57 \\
2017 & $87,803.40$ & 5.26 & $1,091,200$ & 65.43 \\
\hline
\end{tabular}

Figure 7 shows the thermal consumption of the EII building from 2014 to 2017.

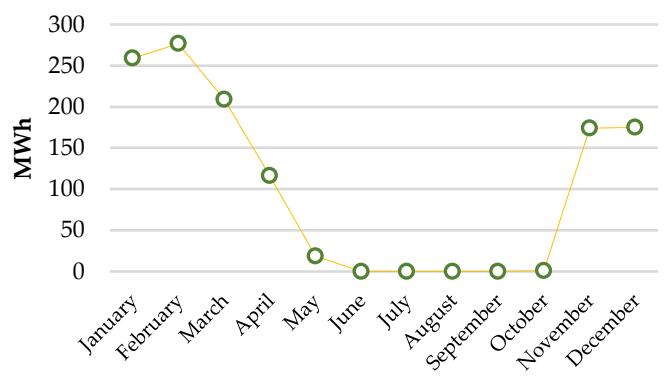

(a)

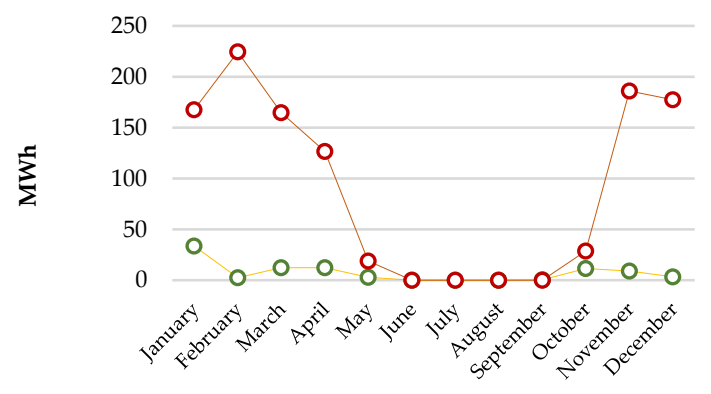

(c)

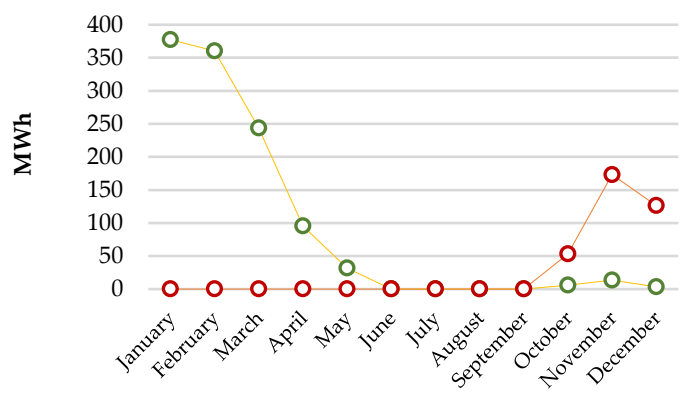

(b)

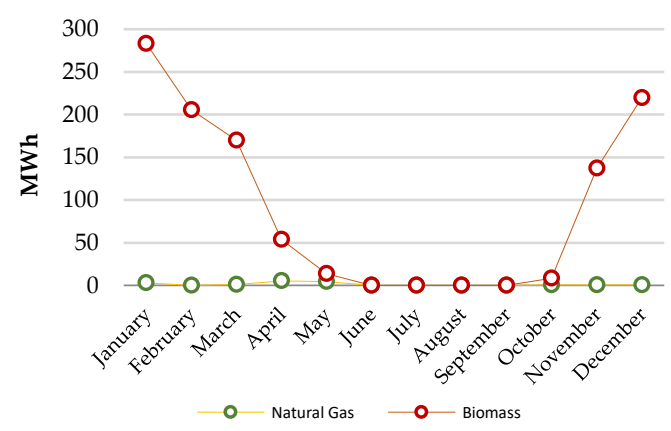

(d)

Figure 7. Thermal consumption of the EII building: (a) 2014; (b) 2015; (c) 2016; (d) 2017.

Figure 8 shows how from 2015 onwards, the energy cost of natural gas decreases and is replaced by the energy cost of biomass itself; each year the cost is lower as the operation of DH stabilizes. 


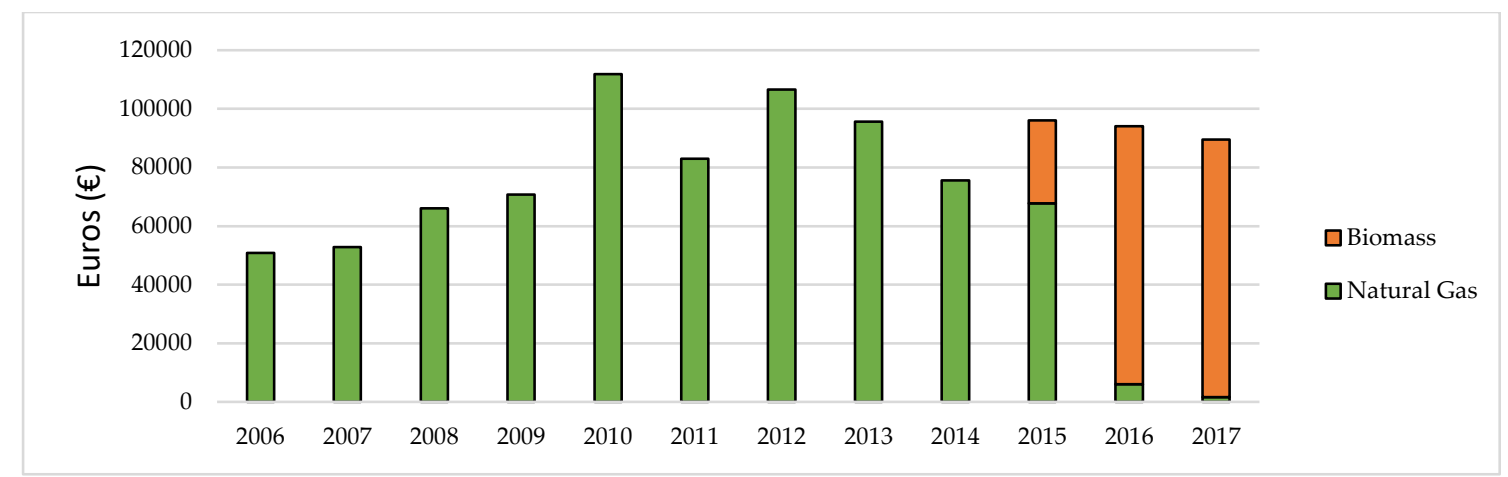

Figure 8. Evolution of the annual thermal cost of heating with NG and biomass DH.

Once the energy consumption, the indicators, their evolution over time have been analyzed, and establishing the energy saving by changing the heating system of the NG system for the new $\mathrm{DH}$ system with biomass, the methodology of the statistical model used in an energy management system ISO 50006 is proposed as an analysis. An energy consumption baseline is selected through a linear regression model, understanding that an Energy Baseline is a quantitative reference that provides the basis for comparing energy performance, allowing the evaluation of energy consumption. In this sense, with the aim of evaluating the impacts of both thermal consumption, economic cost and environmental impact referred to $\mathrm{CO}_{2}$, in the replacement of NG by biomass for EII heating and starting from the Energy Baseline is possible to establish a procedure to predict the calculation of energy consumption of NG in a time period, where DH is used with biomass. The analysis, allows evaluating the energy saving between the District Heating (DH) with biomass and the previous system of NG in the temporary demonstrative period 2016-2017 for EII heating.

For the construction of the Energy Baseline, the NG energy consumption of the 2014/2015 academic year is obtained, the degrees day base 19, for that period of time reference calculated through the climatic data measured in Valladolid and selecting the days of each month where the NG heating system of the EII works. $19^{\circ} \mathrm{C}$ is experimentally justified because through dynamic monitoring with the SCADA system we are aware of the outdoor and indoor temperatures of the building. It also presents the monthly economic cost and the indicators $\left(\frac{\epsilon}{\mathrm{m}^{2}}\right)$ and $\left(\frac{\epsilon}{\mathrm{kWh}}\right)$. All of this data is presented in Table 6.

Table 6. Data for the calculation of the Energy Baseline.

\begin{tabular}{ccccccccc}
\hline Data & $\begin{array}{c}\text { October } \\
\mathbf{2 0 1 4}\end{array}$ & $\begin{array}{c}\text { November } \\
\mathbf{2 0 1 4}\end{array}$ & $\begin{array}{c}\text { December } \\
\mathbf{2 0 1 4}\end{array}$ & $\begin{array}{c}\text { January } \\
\mathbf{2 0 1 5}\end{array}$ & $\begin{array}{c}\text { February } \\
\mathbf{2 0 1 5}\end{array}$ & $\begin{array}{c}\text { March } \\
\mathbf{2 0 1 5}\end{array}$ & $\begin{array}{c}\text { April } \\
\mathbf{2 0 1 5}\end{array}$ & $\begin{array}{c}\text { May } \\
\mathbf{2 0 1 5}\end{array}$ \\
\hline $\begin{array}{c}\text { Degree days } \\
\text { Thermal }\end{array}$ & 29 & 138.1 & 137.4 & 227.8 & 238.6 & 166.6 & 59.3 & 43.3 \\
$\begin{array}{c}\text { Consumption of } \\
\text { NG }(\mathrm{kWh})\end{array}$ & 993 & 173,818 & 174,875 & 377,448 & 360,341 & 243,979 & 95,293 & 31,520 \\
$€$ & & & & & & & & \\
$€ / \mathrm{m}^{2}$ & 198.88 & $10,637.21$ & $10,701.12$ & $22,492.18$ & $21,289.07$ & $14,459.23$ & 5421.08 & 1882.58 \\
$€ / \mathrm{kWh}$ & 0.01 & 0.64 & 0.64 & 1.35 & 1.28 & 0.87 & 0.32 & 0.11 \\
& 0.2003 & 0.0612 & 0.0612 & 0.0596 & 0.0591 & 0.0593 & 0.0569 & 0.0597 \\
\hline
\end{tabular}

Figure 9 represents the Energy Baseline for NG in this reference period, where we relate the thermal consumption of NG kWh versus Degree Days base 19. 


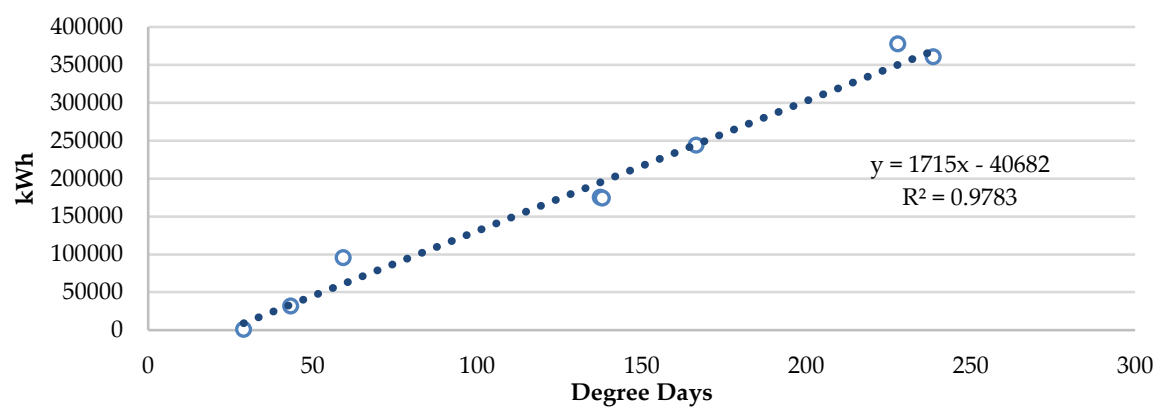

Figure 9. kWh vs. Degree days.

The interpretation of this Energy Baseline is based on the fact that thermal energy consumption is linearly related to the Degree Days, through the equation:

$$
E=m \times(\text { Degree Days })+E_{0}
$$

where there is a fixed energy consumption. $E_{0}$ does not depend on the calculated degrees days and another variable part required to carry out the heating process of the building, $m \times$ (Degree Days). From the regression model the linear equation of the energy baseline is obtained:

$$
C_{(\text {Thermal Consumption })}=1.715 \times(\text { Degree Days })-40.682
$$

In this way, it will be possible to obtain the thermal consumption of the monthly NG in a new temporary heating demonstration period. 2016-2017 can be simply substituted in this linear equation by the new base 19 Degree Days, obtained from a meteorological station in Valladolid for the year 2016/2017, taking the days of operation of the EII heating system.

It is important to interpret these results with respect to the negative $E_{0}$, i.e., the thermal consumption for Degree Days, where it can be observed that as the Degree Days is reduced, base 19 reaches a point at which, due to the inertia and insulation of the building, the thermal loads of heat transfer through it with the exterior are balanced with the internal thermal loads and radiation, so that the temperature of thermal comfort is kept constant and it is not necessary to provide heating for that building. As the base 19 Degree Days continues to be reduced to zero the energy consumption becomes negative, physically this means that the building generates more internal load and radiation than thermal loads by transfer through the building whose energy balance to maintain constant comfort temperature it is necessary to cool the building. Another important consideration is the correlation analysis that allows to measure the degree of relationship between two variables ( $E$ and Degree Days). The measurement of this intensity is evaluated through the correlation coefficient "R2", indicating that the closer to 1 as in our case, 0.9783 stronger will be the linear association between the two variables.

Once validated, the previous linear correlation equation through its Energy Baseline, (Figure 9), we are going to use it to calculate the thermal consumptions of heating in the EII of NG that we would have if the installation of NG continued in the hypothesis that would not have been changed by the new DH system with biomass. For this we use the Degree Days base 19 calculated from the meteorological data in Valladolid 2016/2017. Table 7 shows the results obtained, and also includes the monthly economic costs.

Table 7. Monthly data obtained from thermal NG consumption and economic cost with linear

\begin{tabular}{|c|c|c|c|c|c|c|c|c|}
\hline Data & October 2016 & November 2016 & December 2016 & January 2017 & February 2017 & March 2017 & April 2017 & May 2017 \\
\hline $\begin{array}{c}\text { Degree days } \\
\text { Thermal }\end{array}$ & 63.2 & 190.6 & 145.1 & 203.3 & 179.7 & 152.1 & 67.8 & 29.5 \\
\hline $\begin{array}{l}\text { Consumption } \\
\text { of NG (kWh) }\end{array}$ & 67,706 & 286,197 & $208,164.5$ & $307,977.5$ & $267,503.5$ & $220,169.5$ & 75,595 & 9910.5 \\
\hline$€$ & 9583 & 41,477 & 35,389 & 53,808 & 22,139 & 56,641 & 10,996 & 1470 \\
\hline
\end{tabular}
regression for the 2016/2017 demonstration period. 
Table 8 shows the monthly data for the year 2016-2017, (demonstration period) of the real thermal consumption of NG and DH biomass for heating, with their respective cost. It can be seen that every month has a consumption of biomass for DH but also some thermal consumption of NG, because the DH system in days and hours in 2016-2017 has not been able to maintain all the thermal demand for heating of the EII Building. As can be observed, there are some thermal power peaks, except in February when the DH operated completely without the backup of NG boilers. However, in relation to the economic cost, despite the fact that the thermal consumption of NG in the month of February is non-existent, a fixed rate has to be paid to the NG distributor, the amount of this fee was $108.66 \frac{\epsilon}{\mathrm{kWh}}$.

Table 8. Monthly consumption data for DH fueled by biomass in the EII building from 2016 to 2017.

\begin{tabular}{|c|c|c|c|c|c|c|c|c|}
\hline Data & October 2016 & November 2016 & December 2016 & January 2017 & February 2017 & March 2017 & April 2017 & May 2017 \\
\hline $\begin{array}{l}\text { NG Consumption } \\
(\mathrm{kWh})\end{array}$ & 11,345 & 8908 & 3379 & 2834 & 0 & 851 & 5184 & 4587 \\
\hline$€(\mathrm{NG})$ & 692.99 & 574.22 & 302.57 & 260.61 & 108.66 & 148.5 & 325.05 & 300.78 \\
\hline Biomass (kWh) & 28,700 & 186,100 & 177,400 & 283,300 & 205,600 & 169,800 & 53,800 & 13,800 \\
\hline$€$ (Biomass) & 2309.34 & $14,974.54$ & $14,274.49$ & $23,445.41$ & $17,016.28$ & $14,053.33$ & 4452.7 & 1142.14 \\
\hline$€ /$ kWh (Biomass) & 0.08 & 0.08 & 0.08 & 0.08 & 0.08 & 0.08 & 0.08 & 0.08 \\
\hline$€ /$ kWh (TOTAL) & 0.07 & 0.08 & 0.08 & 0.08 & 0.08 & 0.08 & 0.08 & 0.08 \\
\hline
\end{tabular}

With all these data, will proceed to make economic and environmental savings calculations to compare for the EII building, the NG heating system against the DH system fueled by biomass.

In the regression, a total thermal consumption of NG of 1,443,223 $\mathrm{kWh}$ has been obtained for the annual demonstration period 2016-17 (Table 7) and in the DH system fueled by biomass plus NG backup system, it is 1,155,588 $\mathrm{kWh}$ (Table 8). Therefore, the annual thermal consumption savings and the percentage savings by comparing these two heating systems for the EII building are:

$$
\begin{aligned}
& \mathrm{kWh} \underset{\text { (linear Regression) }}{\mathrm{NG}}=1,443,223 \mathrm{kWh} \\
& \mathrm{kWh}_{16 / 17}=\mathrm{kWh}_{\mathrm{DH}}+\mathrm{kWh}_{\mathrm{NG}}=1,118,500+37,088=1,155,588 \mathrm{kWh} \\
& \text { (Real) } \\
& \text { Thermal Savings }=\mathrm{kWh} \underset{\text { (linear Regression) }}{\mathrm{NG}}-\mathrm{kWh} \underset{\text { (Real) }}{16 / 17}=1,443,223.5-1,155,588=287,635.5 \mathrm{kWh}
\end{aligned}
$$

A $19.9 \%$ savings in thermal consumption is obtained by supplying heating in the EII building by replacing the NG boilers with a DH system fueled by biomass. In relation to the economic costs per year, the same method of calculation is carried out as for energy. The data are obtained from Tables 7 and 8:

$$
\begin{gathered}
€_{\text {(linear Regression) }}^{\mathrm{NG}}=231.507,87 € \\
€_{\substack{16 / 17 \\
\text { (Real) }}}=€_{\mathrm{DH}}+€_{\mathrm{NG}}=91,668.23+2,713.38=94,381.61 €
\end{gathered}
$$

Therefore, the annual Economic Saving in heating comparing both energy systems and its percentage are:

$$
\text { Economic Savings }=€ \underset{\text { (linear Regression) }}{\mathrm{NG}}-€_{\underset{(\text { Real) }}{16 / 17}}=231,507.87-94,381.61=137,126.26 €
$$

A 59.2\% economic savings are obtained for the EII building with the DH system fueled by biomass, compared to the original energy system fueled by NG. In order to analyze the environmental impact, it is necessary to take into account the " $F$ " factor of the type of fuel in current Spanish standards:

$$
\begin{aligned}
F \underset{(\text { Thermal })}{\mathrm{NG}} & =0.252 \frac{\mathrm{kg} \mathrm{CO}_{2}}{\mathrm{kWh}} \\
F \underset{\text { (Thermal) }}{\text { Biomass }} & =0.018 \frac{\mathrm{kg} \mathrm{CO}_{2}}{\mathrm{kWh}}
\end{aligned}
$$


For the environmental impact assessment of the change of the DH system fueled by biomass versus the old energy system fueled by NG, Carbon emissions per year are calculated on the heating consumption at the EII building, between 2016 to 2017, for each energy system. If the energy system fueled by NG were working, its carbon emissions would be:

$$
\begin{gathered}
\mathrm{kg} \mathrm{CO}_{\text {(linear Regression) }}^{\mathrm{NG}}=\mathrm{C} \underset{\text { (linear Regression) }}{\mathrm{NG}} \times F_{\mathrm{NG}} \\
\mathrm{kg} \mathrm{CO} \underset{\text { (linear Regression) }}{\mathrm{NG}}=1,443,223.5 \mathrm{kWh} \times 0.252 \frac{\mathrm{kg} \mathrm{CO}}{\mathrm{kWh}} \\
\mathrm{kg}_{\mathrm{CO}_{2}} \underset{\text { (linear Regression) }}{\mathrm{NG}}=363,692.322 \mathrm{~kg} \mathrm{CO}_{2}
\end{gathered}
$$

To calculate the carbon emissions of the current energy system (DH fueled by biomass + energy system fueled by NG) it is carried out in the same way:

$$
\begin{gathered}
\mathrm{kg}_{\mathrm{CO}_{2}} \underset{(\text { Real })}{\mathrm{NG}}=\left[\mathrm{kWh}_{\mathrm{DH}} \times F_{\text {Biomasa }}+\mathrm{kWh}_{\mathrm{NG}} \times F_{\mathrm{NG}}\right] \\
\mathrm{kg} \mathrm{CO}_{2} \underset{(\text { Real })}{\mathrm{NG}}=\left[\begin{array}{c}
\left.1,118,500 \mathrm{kWh} \times 0.018 \frac{\mathrm{kg} \mathrm{CO}_{2}}{\mathrm{kWh}}+37,088 \mathrm{kWh} \times 0.252 \frac{\mathrm{kg} \mathrm{CO}_{C_{2}}}{\mathrm{kWh}}\right] \\
\mathrm{kg} \mathrm{CO}_{2} \underset{(\text { Real })}{\mathrm{NG}}=29,479.176 \mathrm{~kg} \mathrm{CO}_{2}
\end{array}\right.
\end{gathered}
$$

The environmental impact resulting from the heating system replacement in the EII building, achieves for the 2016-2017 period an annual reduction of carbon emissions of:

$$
\begin{gathered}
\mathrm{kg} \mathrm{CO}_{2 \text { (Savings) }}=\mathrm{kg}_{\mathrm{CO}_{2}} \underset{\text { (linear Regression) }}{\mathrm{NG}}-\mathrm{kg}_{\mathrm{CO}_{2}} \underset{(\text { Real) }}{\mathrm{DH}}-\mathrm{kg}_{\mathrm{CO}_{2}} \underset{\text { (Real) }}{\mathrm{NG}} \\
=363,692.322 \mathrm{~kg} \mathrm{CO}_{2}-29,479.176 \mathrm{~kg} \mathrm{CO}_{2} \\
\mathrm{~kg} \mathrm{CO}_{2 \text { (Savings) }}=334,213 \mathrm{~kg} \mathrm{CO}_{2}
\end{gathered}
$$

A $93.2 \%$ savings in environmental impact with the current energy system compared to the previous one:

$$
\% \text { Increased Renewable Energy }=\frac{\begin{array}{c}
\text { DH } \\
\text { (Biomass) }
\end{array}}{\text { (linear Regression) }}=\frac{1,118,500}{1,443,223.5} \times 100=77.5 \%
$$

Figure 10 shows the performance between DH fueled by biomass versus the NG energy system compared to environmental economic energy savings and increased renewable energy versus the natural gas system from 2016 to 2017.

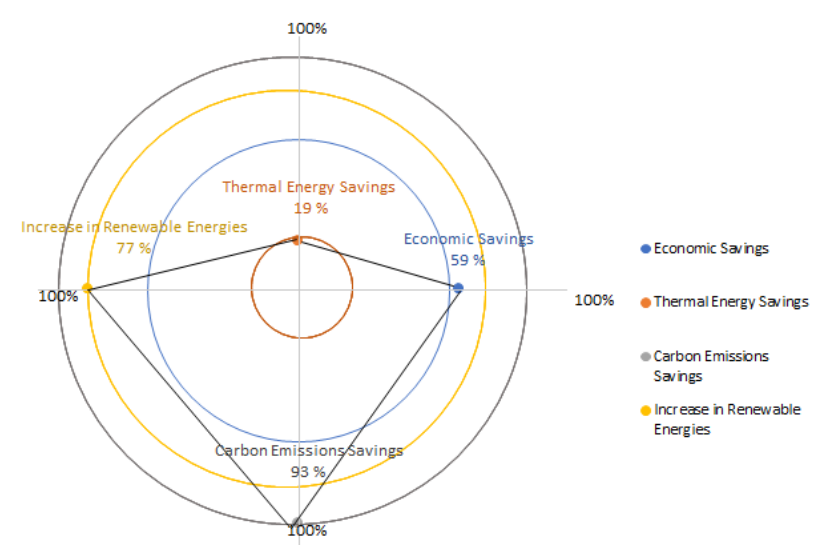

Figure 10. Performance between DH fueled by biomass versus NG energy system from 2016 to 2017. 


\subsubsection{Basic Efficiency Indicator $I_{100}$}

In order to evaluate the energy efficiency of the new heating system for DH EII with biomass, the use of the base $\mathrm{I}_{100}$ is presented as a methodology since it is an energy management tool that allows comparing the performance of the results of the monthly thermal consumption of heating with $\mathrm{DH}$ of biomass, measured in a process during an operative period 2016-2017, with respect to the base or real energy consumption of the same, taking as a reference the dimensionless value of 100:

The Basic Efficiency Indicator 100 is:

$$
I_{100}=\frac{E_{\text {Regression Baseline }}}{E_{r}}
$$

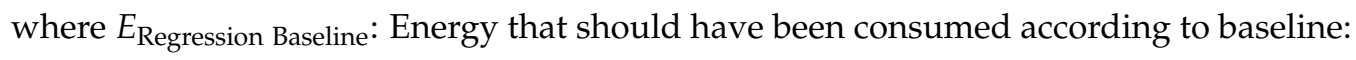

$$
E=m \times(\text { Degree Days })+E_{0}
$$

The result of the Basic Efficiency Indicator can be analyzed according to three states, which are within the numerical ranges $<100,>100,=100$. The interpretation of the efficiency indicator is shown in Table 9.

Table 9. Efficiency Indicator Interpretation.

\begin{tabular}{ccc}
\hline Case & IDE & $\begin{array}{c}\text { Measured Consumption equal to projected with the base equation } \\
\text { There is a decrease in energy performance since the energy } \\
\text { consumption was higher than the baseline. the energy consumed or } \\
\text { measured greater than the baseline energy calculated process with } \\
\text { overconsumption or inefficient }\end{array}$ \\
2nd Case & IDE $=100$ & $\begin{array}{c}\text { There is an improvement in energy performance since energy } \\
\text { consumption was lower than the baseline. }\end{array}$ \\
\hline
\end{tabular}

In the DH system fueled by biomass, the monthly Basic Efficiency Indicator for the period 2016-2017 is obtained from the actual and base monthly thermal consumption by means of the Energy Baseline. The data are presented in Table 10.

Table 10. Monthly Basic Efficiency Indicator for the 2016 to 2017.

\begin{tabular}{ccccccccc}
\hline Efficiency Indicator & $\begin{array}{c}\text { October } \\
\mathbf{2 0 1 6}\end{array}$ & $\begin{array}{c}\text { November } \\
\mathbf{2 0 1 6}\end{array}$ & $\begin{array}{c}\text { December } \\
\mathbf{2 0 1 6}\end{array}$ & $\begin{array}{c}\text { January } \\
\mathbf{2 0 1 7}\end{array}$ & $\begin{array}{c}\text { February } \\
\mathbf{2 0 1 7}\end{array}$ & $\begin{array}{c}\text { March } \\
\mathbf{2 0 1 7}\end{array}$ & $\begin{array}{c}\text { April } \\
\mathbf{2 0 1 7}\end{array}$ & $\begin{array}{c}\text { May } \\
\mathbf{2 0 1 7}\end{array}$ \\
\hline $\begin{array}{c}\text { Actual thermal } \\
\text { consumption } \\
\quad(2016 / 2017)\end{array}$ & 40,045 & 195,008 & 180,779 & 286,134 & 205,600 & 170,651 & 58,984 & 18,387 \\
$\begin{array}{c}\text { Basic consumption } \\
\text { (regression model) }\end{array}$ & 67,706 & 286,197 & $208,164.5$ & $307,977.5$ & $267,503.5$ & $220,169.5$ & 75,595 & $9,910.5$ \\
$\begin{array}{c}\text { Basic Efficiency } \\
\text { Indicator }\end{array}$ & 169.07 & 146.76 & 115.15 & 107.63 & 130.11 & 129.02 & 128.16 & 53.90 \\
\hline
\end{tabular}

Figure 11 shows that most of the months analyzed correspond to values above 100, which indicate a compliance zone for energy performance (increased system efficiency). In May, the value of the indicator is less than 100, which indicates a decrease in efficiency that can be explained, insofar as the demand for heating is much lower than the power generated by the biomass boilers of $\mathrm{DH}$, in addition to being a point of low energy consumption of heat. 


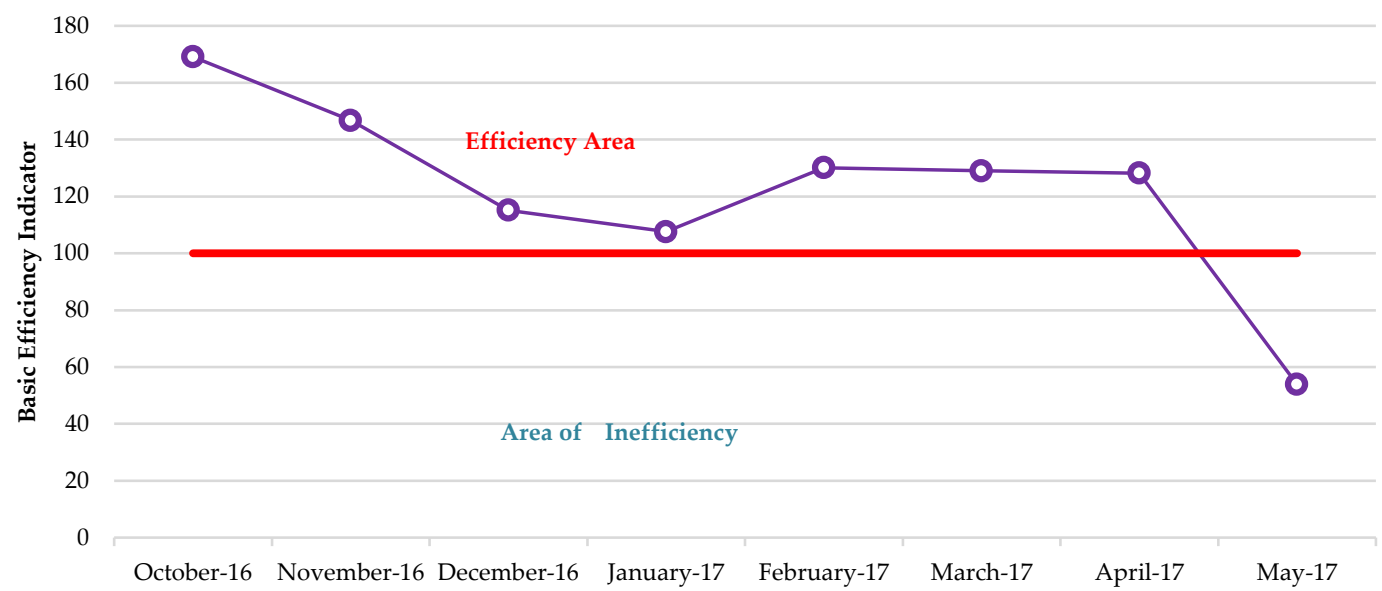

Figure 11. Basic Efficiency Indicator.

\subsubsection{Cusum Indicator}

With the aim of determining quantitatively the magnitude of the energy that has not been consumed, in other words, savings. Besides, the amount that has been overconsumed. The variation of this indicator for the DH system is presented, using for its construction the equation:

$$
\text { Cusum Indicator }=\left(E_{\text {measured }}-E_{\text {trend }}\right)_{i}+\left(E_{\text {measured }}-E_{\text {trend }}\right)_{i-1}
$$

Table 11 shows the cusum indicators for the period 2016 to 2017.

Table 11. Base data for indicator CUSUM for the period 2016 to 2017.

\begin{tabular}{ccccc}
\hline Month & $\begin{array}{c}\text { Energy Linear Regression } \\
\text { 2016/2017 [kWh] }\end{array}$ & $\begin{array}{c}\text { Actual Energy } \\
\text { [kWh] }\end{array}$ & $\begin{array}{c}\text { Actual Energy-Energy } \\
\text { Linear Regression [kWh] }\end{array}$ & Cusum [kWh] \\
\hline October 2016 & 67,706 & 40,045 & $-27,661$ & $-27,661$ \\
November 2016 & 286,197 & 195,008 & $-91,189$ & $-118,850$ \\
December 2016 & $208,164.50$ & 180,779 & $-27,386$ & $-146,236$ \\
January 2017 & $307,977.50$ & 286,134 & $-21,844$ & $-168,079$ \\
February 2017 & $267,503.50$ & 205,600 & $-61,904$ & $-229,983$ \\
March 2017 & $220,169.50$ & 170,651 & $-49,519$ & $-279,501$ \\
April 2017 & 75,595 & 58,984 & $-16,611$ & $-296,112$ \\
May 2017 & 9910.50 & 18,387 & 8477 & $-287,636$ \\
\hline
\end{tabular}

Therefore, this indicator shows any energy savings or over-consumption, or in economic terms related to energy, that the EII Building has had. The figure is used to track the trend of the process, in terms of the variation of its energy consumption, with respect to an energy period or baseline used as a reference. Figure 12 shows the CUSUM Indicator since 2016 to 2017.

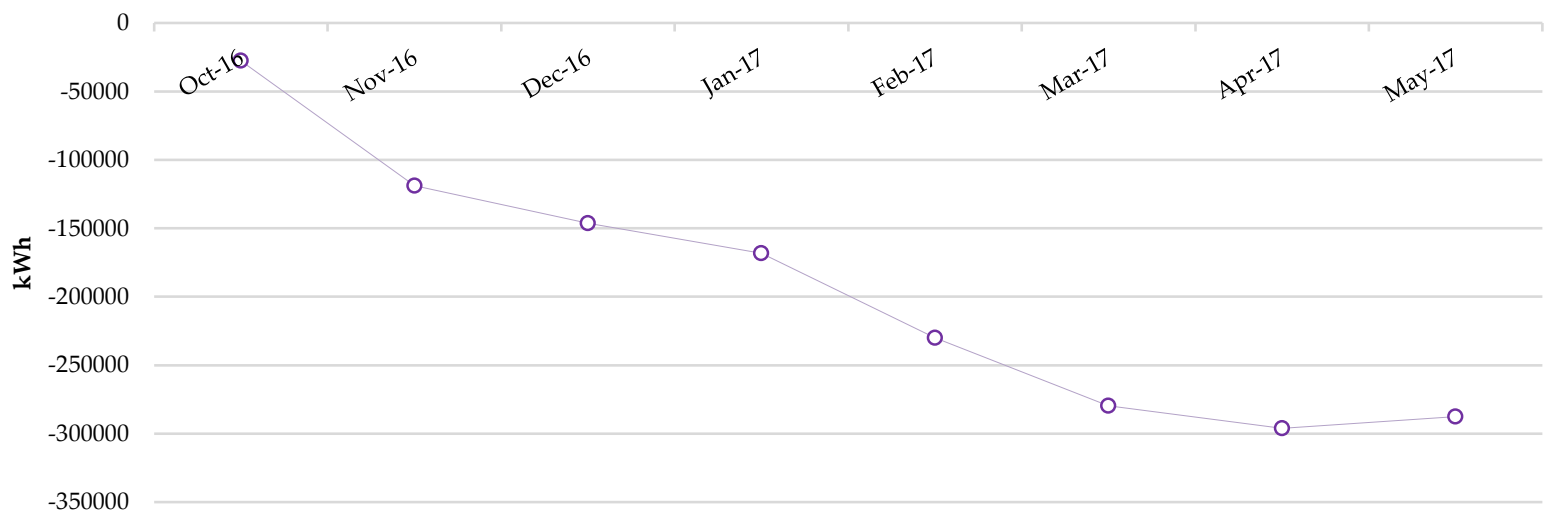

Figure 12. CUSUM indicator for the period 2016 to 2017. 
If there is no change in consumption patterns, the CUSUM curve will simply fluctuate around a horizontal line. However, any change that produces savings or overconsumption will cause the curve to change direction: a downward trend in the curve means savings, while upward trend means losses.

\subsubsection{The Primary Energy Indicator}

All supplied and exported energies are shown in a unique indicator. The Primary Energy Indicator [24]. It is estimated from the energy supplied and exported using the national primary energy factor provided by Equation (20):

$$
\begin{gathered}
E_{\mathrm{p}, \text { nrem }}=\sum_{i}\left(E_{\text {del }, \mathrm{i}} f_{\text {del,nren }, \mathrm{i}}\right)-\sum_{i}\left(E_{\text {exp }, \mathrm{i}} f_{\text {del }, \text { exp }, \mathrm{i}}\right) \\
E P_{\mathrm{p}}=\frac{E_{\mathrm{p}, \text { nrem }}}{A_{\text {net }}}
\end{gathered}
$$

The near zero performance is determined by a Member State in terms of the achievable use of primary energy, the amount of primary energy supplied by renewable energies, the funding sources available for renewable energies or measures of energy efficiency, and the funding requirements as well as the successful rate of the definition.

The nZEBs such as a national use of energy which is both technologically and economically feasible of $>0 \frac{\mathrm{kWh}}{\mathrm{m}^{2} \cdot \mathrm{y}}$, but no higher than the existing Member State threshold for primary non-renewable energy, generated by a mix of best-practice eco-efficiency measures plus renewable energy systems that might or might not be cost-optimal.

Spain has not yet laid down this limited value; however a draft document already exists for the Spanish Building Standard, in which bases for the nZEB definition are argued. December 2016, Spain launched a report to improve the evaluation methodology in high-efficiency buildings. This report suggests several predefined thresholds based on those defined in July 2016, in Commission Recommendation (EU) 2016/1318.

In Valladolid, which is marked by a continental climate, such upper limits are 85 to $100 \frac{\mathrm{kWh}}{\mathrm{m}^{2} \cdot \mathrm{y}}$, of primary energy consumption in total on these buildings per year. At this point, the upper limits for non-renewable sources are between 45 and $55 \frac{\mathrm{kWh}}{\mathrm{m}^{2} \cdot \mathrm{y}}$, and the contribution of renewable energies to primary energy must be greater than $45 \frac{\mathrm{kWh}}{\mathrm{m}^{2} \cdot \mathrm{y}}$.

In order to assess compliance with upper limits for primary energy, primary energy intensity at the buildings is established. The methodology for the determination applies the approach defined in the general EPBD regulation. Primary energy is obtained as the biomass heat being multiplied by its respective Primary Energy Factor (PEF). Moreover, in Spain, these factors are established in its own normative, the Spanish Thermal Systems Standard. [25]. The Table 12 shows the primary energy factors by each energy sources.

Table 12. Spanish Building Standards. PEF established.

\begin{tabular}{ccccc}
\hline Energy & Source & Use & $f_{\text {p,ren }}$ & $f_{\text {p,nren }}$ \\
\hline Electricity & Grid & Input & 0.414 & 1.954 \\
Biomass & On-site & Input & 1.003 & 0.034 \\
Natural Gas & On-site & Input & 0.005 & 1.190 \\
\hline
\end{tabular}

Non-renewable conversion factor $f_{\mathrm{i}}$ applied to the electricity, in Spain, is currently 1.954. Biomass conversion factor is 1 . At the EII Building there is still no export energy, so the primary energy indicator is:

$$
E P_{\mathrm{p}}=118.15 \frac{\mathrm{kWh}}{\mathrm{m}^{2} \cdot \mathrm{y}}
$$


This is caused by the main factors established by Spain, which has a higher percentage of renewable energy (17\%) from the main electricity grid. by calculating the on-site RES share; it is possible to obtain a high value of $91.21 \frac{\mathrm{kWh}}{\mathrm{m}^{2} \cdot \mathrm{y}}$ of contribution of renewable primary energies in situ at EII Building. A primary energy comparison between the EII Building versus the assumptions of the European Union Directive is shown in Figure 13.

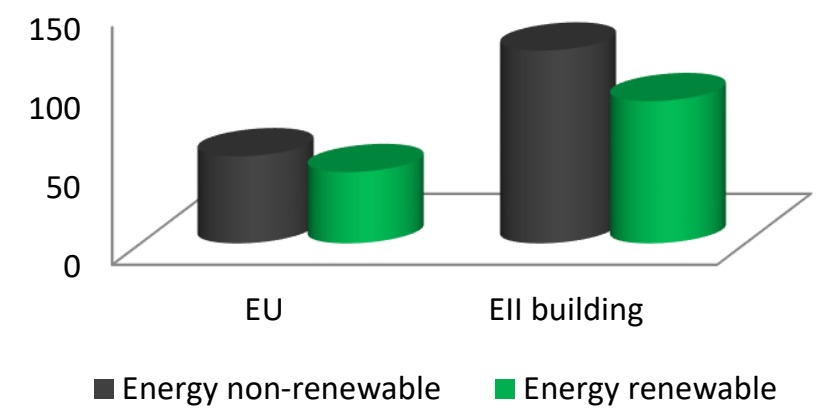

Figure 13. Primary energy comparison between EII Building and EU Directive.

The detailed boundary values of the system for determining the energy supplied and exported are added based on the reference limits of EN15603. As started in the EPBD recast, the positive influence of renewable energy produced on site is taken into account, so that it reduces the amount of energy supplied needed and can be exported when the demand of buildings is exceeded [26].

\subsubsection{Renewable Energy Ratio}

To calculate the amount of renewable energies used through the Renewable Energy Ratio (RER), all sources of renewable energy must be taken into account [24]. Solar thermal energy, photovoltaic energy, wind and hydro power, renewable energy from environmental heat sources such as heat pumps and free cooling, renewable biofuels and off-site renewable energy are included. The environmental heat sources used in heat pumps and free-cooling should be considered within the limit of the use of renewable energy system, because in the calculation of the RER, free cooling and heat pumps are not only accounted for in the calculation of the energy supplied on the basis of the COP, it is also taken into account in the energy obtained from the environmental heat sources.

The proportion of renewable energies are obtained in relation to the energy use at the building, as total primary energy. It keeps in mind that the exported energy compensates for the energy delivered. By default, the export energies are deemed to compensate for the grid mix or for thermal energy, the grid mix of district cooling or heating. For near and on-site renewable energies, the overall primary energy factor is 1.0, while the primary non-renewable energy factor is 0 .

The total primary energy-based RER is given by the following Equation (23):

$$
R E R_{\mathrm{p}}=\frac{\sum_{\mathrm{i}} E_{\text {ren }, \mathrm{i}}+\sum_{\mathrm{i}}\left(\left(f_{\text {del,tot }, \mathrm{i}}-f_{\text {del, nrem }, \mathrm{i}}\right) E_{\text {del, } \mathrm{i}}\right)}{\sum_{\mathrm{i}} E_{\text {ren, }, \mathrm{i}}+\sum_{\mathrm{i}}\left(E_{\text {del }, \mathrm{i}} f_{\text {del, }, \text { tot }, \mathrm{i}}\right)-\sum_{\mathrm{i}}\left(E_{\text {exp }, \mathrm{i}} f_{\text {exp }, \text { tot }, \mathrm{i}}\right)}
$$

In order to get the $R E R_{\mathrm{p}}$ for the EII building, $f_{\mathrm{i}}=1.954$ is taken for electricity and $f_{\mathrm{i}}=1.003$ for the biomass and $f_{\mathrm{i}}=0.005$ for natural gas:

$$
R E R_{\mathrm{p}}=0.424
$$

Thus, the RER, the third indicator, in the EII Building is 0.424 , a figure that represents a pretty strong result for a nZEB. 


\section{Conclusions}

A new analysis methodology is developed, based on the ISO 50001 standard, for the implementation of new thermal systems in building renovations using DH. Following the objectives proposed by the EU 20-20-20, in this research paper several indicators have been studied to analyze how the change from a NG heating system to a new heating system by a DH fueled by biomass on an educational building, Engineering School (EII) at the University of Valladolid in Spain.

The proposed indicators as well as the methodology carried out fulfill the established methodology in an SGEn ISO 50001, in order to analyze the reduction of thermal energy and the heating efficiency of the building with the new DH as well as the economic costs and environmental impact. Finally, three new indicators of non-renewable primary energy, renewable energy and RER are determined in accordance with the methodology proposed by EU EN15603 and EPBD 2018 on nZEB buildings.

With them it is possible to determine the level of impact in the change towards the $\mathrm{DH}$, without altering the energy demand of the building, looking for this existing building to look like a building nZEB.

The results obtained show that the new DH system fueled by biomass in the period 2016-2017 achieved a percentage of thermal savings of $19.9 \%$, an economic saving of $59.2 \%$, a carbon emissions saving of $93.2 \%$, and an increase in renewable energy of $77.5 \%$.

The $\mathrm{I}_{100}$ indicator has also been calculated and it can be seen that the DH system works in an energy efficiency zone, as well as the Cusum indicator where its graph shows that the DH over the entire time interval has a tendency to improve energy efficiency. The $\mathrm{I}_{100}$ indicator has also been calculated and it can be seen that the DH system works in an energy efficiency zone, as well as the Cusum Indicator where its graph shows that the DH over the entire time interval has a tendency to improve energy efficiency.

The non-renewable and renewable primary energy indicators of the new DH system fueled by biomass have been calculated at $118.15 \frac{\mathrm{kWh}}{\mathrm{m}^{2} \cdot \mathrm{y}}, 91.21 \frac{\mathrm{kWh}}{\mathrm{m}^{2} \cdot \mathrm{y}}$, respectively. They have been compared by the values that the EU proposes for a city like Valladolid and it is observed that the non-renewable primary energy is of the order of the double, this is due that although the $\mathrm{DH}$ reduces in a $40 \%$ with respect to the old system of NG, to the lack of any improvement in the energetic demand of the building EII does that this value is still high.

On the other hand, however, the comparison of primary renewable energy from DH reaches a value of double, so that the integration of renewable energy by the change from NG to biomass gives a high RER of 0.4. Use of these indicators proposed by the EU enables us to conclude that the change in the EII building of the new DH system fueled by biomass achieves an approximation towards the nZEB building status.

Author Contributions: Conceptualization F.J.R.M., J.S.J.A. and E.V.G.; Methodology, F.J.R.M., R.C.M. and J.M.R.H.; Validation, F.J.R.M., J.S.J.A. and E.V.G.; Formal Analysis, R.C.M. and J.M.R.H.; Investigation, R.C.M. and J.M.R.H.; Resources, F.J.R.M., J.S.J.A. and E.V.G.; Data Curation, R.C.M.; Writing-Original Draft Preparation, R.C.M.; Writing-Review \& Editing, J.M.R.H.; Visualization, F.J.R.M., J.S.J.A. and E.V.G.; Supervision, F.J.R.M.

Funding: This research received no external funding.

Acknowledgments: The support of La Dirección de Investigaciones y Desarrollo Tecnológico (DIDT) de la Universidad Autónoma de Occidente (UAO) in Cali, Colombia, and the RETO GIRTER Project (New Intelligent Manager for Thermal Networks), project funded by the European Regional Development Fund through the Ministry of Economy, Industry and Competitiveness of the Government of Spain, have made this research paper feasible.

Conflicts of Interest: The authors declare no conflict of interest. 


\section{Abbreviations}

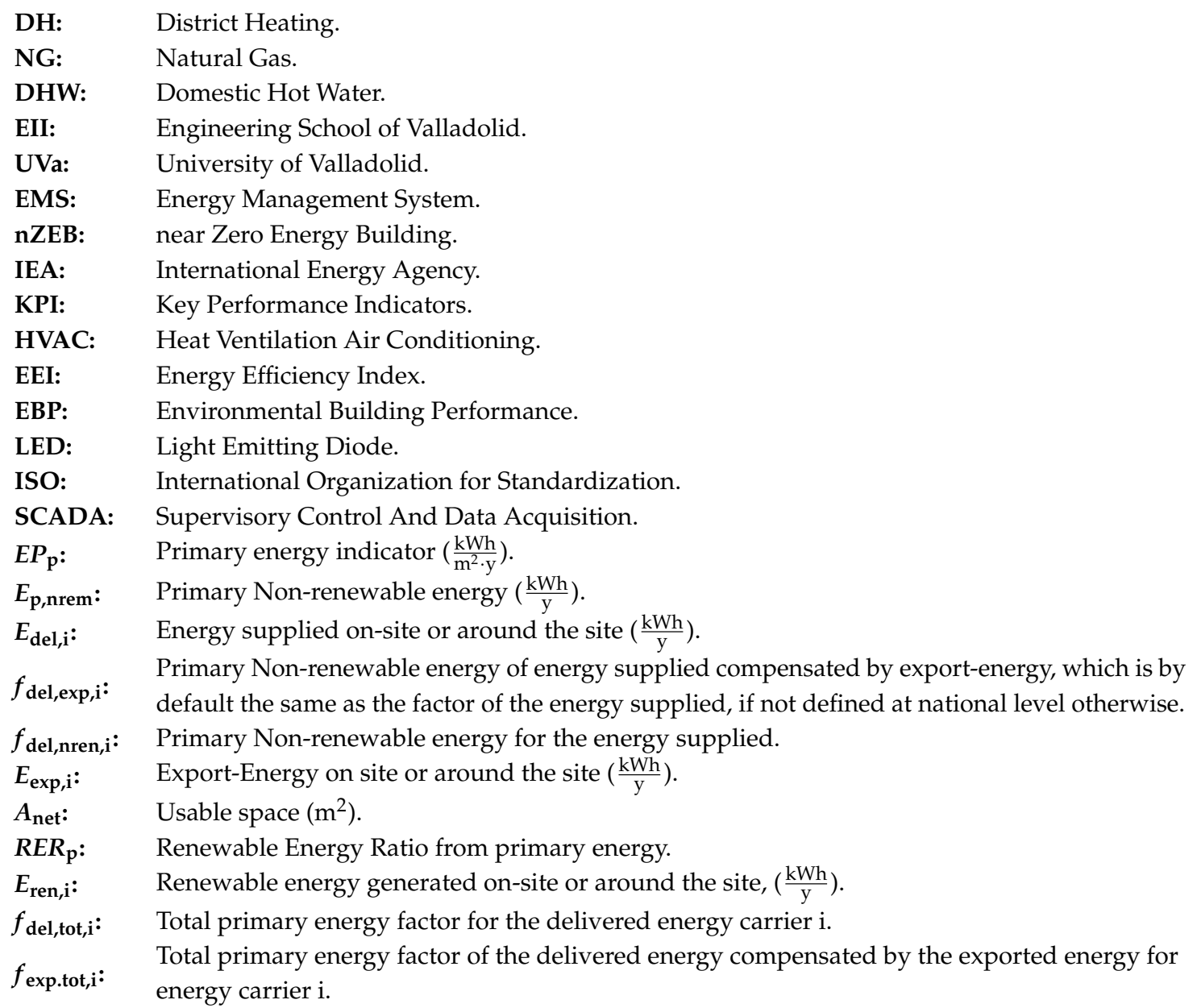

\section{References}

1. Mazhar, A.R.; Liu, S.; Shukla, A. A state of art review on the district heating systems. Renew. Sustain. Energy Rev. 2018, 96, 420-439. [CrossRef]

2. Gao, L.; Cui, X.; Ni, J.; Lei, W.; Huang, T.; Bai, C.; Yang, J. Technologies in Smart District Heating System. Energy Procedia 2017, 142, 1829-1834. [CrossRef]

3. Lund, H.; Duic, N.; Østergaard, P.A.; Mathiesen, B.V. Future district heating systems and technologies: On the role of smart energy systems and 4th generation district heating. Energy 2018, 165, 614-619. [CrossRef]

4. Werner, S. District heating and cooling in Sweden. Energy 2017, 126, 419-429. [CrossRef]

5. Lygnerud, K.; Werner, S. Risk assessment of industrial excess heat recovery in district heating systems. Energy 2018, 151, 430-441. [CrossRef]

6. Schmidt, D. Low Temperature District Heating for Future Energy Systems. Energy Procedia 2018, 149, 595-604. [CrossRef]

7. Turski, M.; Sekret, R. Buildings and a district heating network as thermal energy storages in the district heating system. Energy Build. 2018, 179, 49-56. [CrossRef]

8. Fallahnejad, M.; Hartner, M.; Kranzl, L.; Fritz, S. Impact of distribution and transmission investment costs of district heating systems on district heating potential. Energy Procedia 2018, 149, 141-150. [CrossRef]

9. Lidberg, T.; Gustafsson, M.; Myhren, J.A.; Olofsson, T.; Ödlund (former Trygg), L. Environmental impact of energy refurbishment of buildings within different district heating systems. Appl. Energy 2018, 227, 231-238. [CrossRef]

10. Bücker, D.; Jell, P.; Botsch, R. Performance monitoring of rural district heating systems. Energy Procedia 2018, 149, 5-14. [CrossRef] 
11. Wu, W.; Skye, H.M. Net-zero nation: HVAC and PV systems for residential net-zero energy buildings across the United States. Energy Convers. Manag. 2018, 177, 605-628. [CrossRef]

12. Zinzi, M.; Pagliaro, F.; Agnoli, S.; Bisegna, F.; Iatauro, D. Assessing the overheating risks in Italian existing school buildings renovated with nZEB targets. Energy Procedia 2017, 142, 2517-2524. [CrossRef]

13. Nielsen, S.; Möller, B. Excess heat production of future net zero energy buildings within district heating areas in Denmark. Energy 2012, 48, 23-31. [CrossRef]

14. Sekki, T.; Airaksinen, M.; Saari, A. Effect of energy measures on the values of energy efficiency indicators in Finnish daycare and school buildings. Energy Build. 2017, 139, 124-132. [CrossRef]

15. Abu Bakar, N.N.; Hassan, M.Y.; Abdullah, H.; Rahman, H.A.; Abdullah, M.P.; Hussin, F.; Bandi, M. Energy efficiency index as an indicator for measuring building energy performance: A review. Renew. Sustain. Energy Rev. 2015, 44, 1-11. [CrossRef]

16. Maslesa, E.; Jensen, P.A.; Birkved, M. Indicators for quantifying environmental building performance: A systematic literature review. J. Build. Eng. 2018, 19, 552-560. [CrossRef]

17. International Organization for Standardization (ISO). Available online: https://www.iso.org/ (accessed on 14 September 2018).

18. Van der Hoeven, M. Energy Efficiency Indicators: Essentials for Policy Making. Available online: https://webstore. iea.org/energy-efficiency-indicators-essentials-for-policy-making (accessed on 5 November 2018).

19. González, A.J.; Castrillón, R.; Quispe, E.C. Energy Efficiency Improvement in the Cement Industry through Energy Management. In Proceedings of the 2012 IEEE-IAS/PCA 54th Cement Industry Technical Conference, San Antonio, TX, USA, 14-17 May 2012. [CrossRef]

20. Benedetti, M.; Cesarotti, V.; Introna, V. From energy targets setting to energy-aware operations control and back: An advanced methodology for energy efficient manufacturing. J. Clean. Prod. 2017, 167, 1518-1533. [CrossRef]

21. Al-Saadi, S.N.J.; Ramaswamy, M.; Al-Rashdi, H.; Al-Mamari, M.; Al-Abri, M. Energy Management Strategies for a Governmental Building in Oman. Energy Procedia 2017, 141, 206-210. [CrossRef]

22. Afroz, Z.; Higgins, G.; Urmee, T.; Shafiullah, G. Technological Advancement of Energy Management Facility of Institutional Buildings: A Case Study. Energy Procedia 2017, 142, 3088-3095. [CrossRef]

23. Castrillon, R.; González, A. Metodología Para la Planificación Energética a Partir de la Norma ISO 50001; Editorial Universidad Autónoma de Occidente: Cali, Colombia, 2018; ISBN 978-958-8994-59-8.

24. Rey-Hernández, J.M.; Velasco-Gómez, E.; San José-Alonso, J.F.; Tejero-González, A.; Rey-Martínez, F.J. Energy analysis at a near zero energy building. A case-study in Spain. Energies 2018, 11, 857. [CrossRef]

25. CTE (Spanish Technical Building Code). Available online: http://www.codigotecnico.org (accessed on 15 September 2018).

26. European Directives. Available online: http:/ / eur-lex.europa.eu/ (accessed on 14 September 2018). 